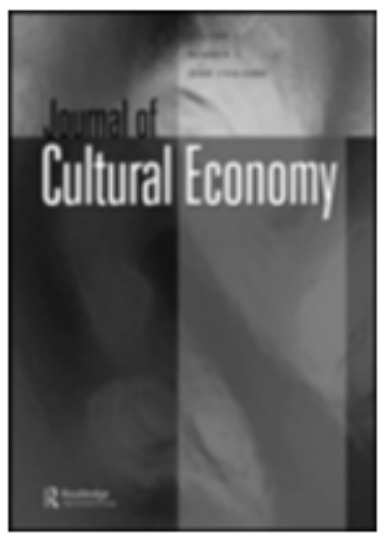

\title{
Knows No Weekend: The Psychological Contract of Cultural Work in Precarious Times
}

\begin{tabular}{|r|l|}
\hline Journal: & Journal of Cultural Economy \\
\hline Manuscript ID & RJCE-2018-0001.R2 \\
\hline Manuscript Type: & Special Issue Article \\
\hline Keywords: & aesthetics, labour, cultural industry, social reproduction, subjectivity \\
\hline
\end{tabular}

\section{SCHOLARONE \\ Manuscripts}




\title{
Knows No Weekend: The Psychological Contract of Cultural Work in Precarious Times
}

\author{
Authors: \\ Dr. Stevphen Shukaitis (corresponding author) \\ Senior Lecturer (Associate Professor) in Culture \& Organization \\ University of Essex \\ Essex Business School \\ Wivenhoe Park \\ Colchester CO4 3SQ \\ Telephone: $+44(0) 1206874283$ \\ e-mail: $\underline{\text { sshuka@essex.ac.uk }}$
}

Stevphen Shukaitis is Senior Lecturer at the University of Essex, Centre for Work and Organization, and a member of the Autonomedia editorial collective. Since 2009 he has coordinated and edited Minor Compositions (http://www.minorcompositions.info). He is the author of Imaginal Machines (2009), The Composition of Movements to Come (2016), Combination Acts (2019), and editor (with Erika Biddle and David Graeber) of Constituent Imagination: Militant Investigations // Collective Theorization (AK Press, 2007). His research focuses on the emergence of collective imagination in social movements and the changing compositions of cultural and artistic labour.

Joanna Figiel

Joanna Figiel is a $\mathrm{PhD}$ candidate at the Centre for Cultural Policy and Management, City, University of London. e-mail: joanna.figiel.1@city.ac.uk 


\title{
Knows No Weekend: The Psychological Contract of Cultural Work in Precarious Times
}

\begin{abstract}
This article explores the expanded and transformed nature of the psychological work contract for forms of cultural and artistic labour in precarious conditions. The forms of passionate work found within cultural production are argued to form a new model for governing our subjective involvement in and attachment to work. This more expansive and demanding relationship with work has become generalized beyond the specific area of cultural production into employment relationships more generally. In doing so the expanded psychological contract of work comes to operate as a form of logistical media and infrastructural governance, connecting the micropolitics of governing labour with larger structural conditions of precarity and instability. Thus, while work today is less stable in what it offers, it demands even greater psychological investment despite increased uncertainty.
\end{abstract}

Keywords: artistic and cultural labour, entrepreneurship, institutional critique, Joseph Beuys, psychological contract, social reproduction, subjectivity

The aesthetic force of production is the same as that of productive labour and has the same teleology; and what may be called aesthetic relations of production-all that in which the productive force is embedded and in which it is active-are sedimentations or imprintings of social relations of production. Art's double character as both autonomous and fait social is incessantly reproduced on the level of its autonomy. - Theodor Adorno (1997: 6)

In 1971, the curator and gallerist Rene Block asked Joseph Beuys to produce something for an ongoing series of prints and portfolio he was assembling entitled "Weekend." Beuys is said to have responded to this request with the comment, "Ich kenne kein Weekend," or, "I know no weekend." But rather than just giving a flippant reply, Beuys then proceeded to produce a piece for a series with that very name, one which was compromised of a Maggi sauce bottle and a copy of Immanuel Kant's Critique of Pure Reason emblazoned with the text "BEUYS - Ich Kenne Kein Weekend," mounted inside a suitcase along with a series of other prints. In subsequent years, Beuys made a series of lithograph prints using the same text. And in 2014, Rene Block chose Beuys's response as the title for the exhibition marking the $50^{\text {th }}$ anniversary of his Berlin gallery.

While Beuys's initial reply might seem like a pithy come back to an invitation that he may or may not have appreciated, it did indeed hit upon a truth that resonates more deeply than it might appear at first. Whether one believes in the possibility of exercising pure reason in the fashion Kant thought it possible, in his response Beuys expresses something that has become much more commonly realized and analysed today, namely the apparent impossibility for those engaged in artistic and cultural work to find an outside to their labour. As an artist, Beuys is best known for formulating his artistic practice as participatory and democratic, which he referred to as 'social sculpture,' and for his argument that 'everyone is an artist.' In the workings of today's cultural and creative economy, ever-larger sections of the population are engaged in activities that have been characterized as demonstrating their position in the 
creative class, or as part of a broader transformation of the economy where forms immaterial and cultural production occupy an increasingly central role.

This essay will explore a somewhat different, and a more specific, focus - that is, to begin to develop an analysis starting from Beuys' statement and reflections emerging from our research project, Metropolitan Factory. To take seriously the claim that Beuys makes, that it is not possible for him to know a weekend, to know an outside of work, would mean that for those engaged in artistic and cultural work there is also a transformed relationship to work itself. What Beuys gestures to in that claim is the suggestion that artistic forms of labour transform the psychological contract of work, or the informal expectations and norms around the meaning and practices of working. ${ }^{1}$ For Beuys, to be an artist is to make peace with the reality that there can be no outside to one's work, that every moment could be seized upon as a space of production, and thus there could be no space of respite from work, no weekend retreat. Pascal Gielen, in his book The Murmuring of the Artistic Multitude, argues that the modern art world has played a central role in the movement of ideas of creativity, innovation, flexibility into workings of the economy and labour markets: "the social structure of the early modern art world was one of the social laboratories in which the current Post-Fordian work ethic was produced" (2009: 2). That is to say, this idea that Beuys succinctly expressed of having no outside to work, was first developed within the social laboratory of artistic practice, but arguably has now become more generalized as model of working and relationship with work.

In the Metropolitan Factory research project, we sought - via adapting and employing the practices of workers' inquiry - to look into how transformations in cultural work in the metropolis affected cultural workers' relationship to their work. ${ }^{2}$ An exploration of the micropolitics of creative and cultural work, this research project took as its point of departure the artist Carl André's identification of the artist with the factory worker. ${ }^{3}$ To this end, we conducted a survey and series of interviews based on Marx's original workers' inquiry questionnaire - a hundred questions posed to factory workers in England, in 1880, in order to establish their material working conditions and potentially encourage them to take up political action in order to improve them. Based on this, the methodology of workers' inquiry was formulated within autonomist movements as a sort of parallel sociology, one based on a re-reading of Marx and Weber against established parties and unions. In many ways, it is close to practices of participatory action research. For the 'Metropolitan Factory' project, the original questionnaire was 'updated' and in a way adapted to analyze the working conditions, the autonomy, and activities of independent cultural producers active in former trade areas, such as Brick Lane in London. Discussions of precarity in this essay are based on research on working conditions from a certain array of cultural workers in a relatively prosperous metropolis. The precarity experienced by these workers should not be taken as standing in for the varieties of experience affecting a wider range of precarious workers, from migrant workers in Shenzen to garbage pickers in Rio. A broader essay, or likely book, would need to engage with the range of these different positions grouped together through the concept of precarity. This is outside of the scope of this paper. 
Our aim behind this research activity - which consisted of around one hundred surveys and around twenty in-depth, semi-structured interviews with creative and cultural workers and artists - was to investigate the material realities of those working in this broadly-conceived sphere of creative and cultural production: their conditions of labour - including wages, precarity, rights - as well as of the social reproduction of their labour power. In sum, we attempted to illuminate the lived realities of creative workers, the micro-politics of artistic and cultural work, as well as issues linking this type of activity to issues related to social reproduction (Shukaitis and Figiel, 2015).

We have looked at the spatial organization of the creative process, the language used to describe the relationship between private life and work, and the understanding of work as a form of artistic and professional self-expression (2013). Among the topics that appeared in our interviews and discussions with people working in the field of culture, one of the most frequently raised was about empowerment at work and through work, i.e. the nature of attachment and relationship to work in itself. Cultural workers have repeatedly described their projects not only as forms of work, but also as deep and personal in their essence, functioning in the form of authentic self-expression. Another interesting aspect of the creative process was the way their artistic and creative work was organized and separated from other areas of existence. There was a visible trend towards spatial separation of work from the rest of their life, whether through studio work or storing materials in a specific part of the home. Despite these attempts, the spaces dedicated exclusively to work turned out to be insufficient. Moving the job outside its boundaries was alternatively celebrated (I can work anywhere!), or described in less positive terms (I end up working everywhere!). The further part of the research consisted in the analysis of similarities between the work of the artist - treated as giving meaning and constituting the basis for the existence of an individual - and various forms of feminized activities undertaken in the field of social reproduction, such as housework and care work.

If the condition that Beuys describes was one freely embraced by artists as a mode of integrating work and life into an overall mode of living and way of being in the world, since then it has shifted to something more generalized, and arguably more pernicious. This 'knows no weekend' formulation of integrating life and work forms of the basis of what Sharon Zukin theorizes (1989) as the 'artistic mode of production,' where the lifestyle of artists and their efforts to integrate work and life form a kind of psychological template that the middle classes want to emulate in their living conditions. And it is this idea, this perception of the Bohemian lifestyle, which has fuelled the development and gentrification of cities starting with Manhattan and then replicated countless times around the world. The irony is that while the norm of having a high emotional and psychological investment in one's work has become a much more prevalent expectation, it has been accompanied by a much greater degree of uncertainty and stability in working conditions: the becoming-precarious of increasingly vast swathes of formerly secure and permanent forms of employment. It is part of what Martijn Konings (2015) describes as the 'emotional logic of capitalism,' one which far from eroding attachments rather tends to foster new ones. It is these attachments that structure the ways in 
which the future is conceived, always tying it back to work, but less of any sense of security around it. Or as Melissa Gregg describes it, the condition experienced by workers today "is to be invested in work as and when required but without the reciprocal assurance from employers that commitment will be rewarded. Such a scenario risks losing the goodwill of employees permanently" (2011: 165). In other words, today it is increasingly common to expect that people will work like artists in the sense Beuys describes, but with ever diminishing guarantees that the high degree of their commitment to work will be rewarded in any way.

Maurizio Lazzarato has argued that the dynamics of the new economy, with higher subjective investment in forms of symbolic, creative, and immaterial labour, has "all been absorbed by the debt economy" (2012: 8). Following Ned Rossiter, we could say that it has been likewise absorbed and mitigated by the dynamics of the logistical economy and its nightmares (2016; Cowen, 2014). The question then is what directs and organizes the interface between the highly subjective mode of labour management through the high investment of psychological and libidinal energies, and the more dispersed logistical arrays of capture and governance. Or as Rossiter puts it, if "infrastructure makes worlds, then software coordinates them" (2016: $\mathrm{xv}$ ), which is exactly why developing a media theory of logistics is a pressing task. It is, however, still important when developing this more structural level analysis to not let go of the insights from autonomist analysis that focus on the composition and subjectivity of living labour, and its potentials for disruptive and system changing resistance and rebellion. ${ }^{4}$ The violence of logistics might very well have arisen precisely to attempt to contain these potentials, but is never entirely successful. The expanded psychological contract of cultural production is a system update for the software of the neoliberal governance of labour, one that is constantly attempting to reformat and restrict imaginations of the future to be amenable to the needs of financialization.

\section{Work Without Guarantees}

The sociologist John Clammer (2014) has recently suggested that it would be desirable to develop not just a new sociology of art, but rather what he describes as a "sociology from art," taking moments of artistic and cultural production as containing within themselves understandings, perceptions, and modes of organization that can be teased out into more developed sociological understanding. Arguably this statement from Joseph Beuys points to one such possibility for exploring how an expansive and all-embracing relationship to work that is often found by artists and cultural workers, who frequently demonstrate their commitment to their particular practice above all else, can then become generalized as a model of working: a new psychological contract of labour for precarious times.

There is a range of different sociological and theoretical traditions analysing the changing nature of work, labour more generally, and the employment relationship. In recent years, there have been increased efforts to find bridges between some of them and the analysis of arts and cultural production. ${ }^{5}$ These discussions find parallels in the art world in the emergence of institutional critique during the 1960s and 1970s, which develops out of social movement organizing and radical politics as a space where artists can discuss and contest the 
nature of power and authority in the institutions in which they operate, namely galleries and museums. It is interesting, and perhaps somewhat ironic, that despite the focus being on the operations of such institutions, the focus tended to be more on questions of the connections between museums of the military industrial complex, racism and discrimination in the art world, and less on the concrete working conditions of artists (Raunig and Ray, 2009; Fraser, 2005; Alberro and Stimson, 2009). This is of course not to claim that questions about race, gender, and sexuality are not important by any means. Rather than anything, it seems to reinforce what Hans Abbing argues (2004), that artists have an ideological and psychological investment in thinking about their labours as something other than work, something other and exceptional to everyday concerns, which makes it unnerving to talk about one's practice in the same way you might discuss any other form of work. But increasing conditions of precarity and uncertainty, which have become generalized after the dismantling of the Fordist-Keynesian state welfare model, have rendered attempts to continue viewing artistic and cultural work as exceptional to other labour as unviable.

As Hito Steyerl has suggested (2009), if the first wave of institutional critique produced integration into the art institutions, and the second wave worked to achieve representation into those institutions, since then the only integration achieve has been into precarious working conditions. Steyerl suggests that institutional critique has now been weaponised by neoliberal politics, where concerns previously expressed about the nature of power and authority in cultural institutions is now used as a pretext for dismantling of those very institutions:

while critical institutions are being dismantled by neoliberal institutional criticism, this produces an ambivalent subject which develops multiple strategies for dealing with its dislocation. It is on the one side being adapted to the needs of ever more precarious living conditions. On the other, the need seems never to have been greater for institutions that could cater to the new needs and desires that this constituency will create (2009: 19).

This weaponizing of critique develops perhaps much in the same way that it has been argued that the 'new spirit of capitalism' transformed discontent with Fordist labour practices into a justification for more flexible forms of alienation and exploitation. This becomes distilled down into pop managerial versions by people like Daniel Pink (2010) who claim that carrots and sticks, or traditional forms of rewards and discipline, have become outmoded for today's world of work, which instead requires an embracing of the principles of autonomy, mastery, and purpose. Arguably it is a desire for the ability to work in a self-directed fashion, to be able to be one's own boss, that motivates both those pursuing particular forms of artistic and cultural practice, and entrepreneurs.

This is what Steyerl gestures to as the ambivalent subject who is dislocated. The initial motivating drives have become generalized as a form of ubiquitous labour discipline, one that is all the more effective precisely because it operates through a dispersed and self-organized form of imposition. Artistic and cultural workers, rather than finding themselves confronted 
by a boss or a manager issuing orders and disciplining their work, find themselves confronting themselves finding ever more complex ways to squeeze time and energy out of their own creative work, but also other paid 'gigs', jobs, and often other - sometimes unpaid commitments required to keep them afloat. While Beuys might have known no weekend as a freely embraced choice, for precarious artistic and cultural workers today trying to make ends meet, it can become rather difficult to make any other choice. Directly confronting or questioning this logic is all the more difficult precisely because of the deep seated psychological investment in the work, in a form of artistic and cultural practice, which can easily end up being as much about forming a psychological sense of identity as being a form of labour.

\section{Marx On Silkworms \& the Labour of the Self}

One productive avenue for exploring this deep-seated psychological investment in work can be found in a suggestive argument that Marx makes in exploring the difference between productive and unproductive work, or more specifically between work that is productive for capital versus that which is not. To make this distinction he brings up rather curiously the figure of John Milton, the author of Paradise Lost, a celebrated piece of literature which is widely regarded as one of the best-known epic poems ${ }^{6}$. But as Marx points out, from the perspective of capital and value production, Milton is far from being a productive worker. How is that so? Simply because Milton engaged with an epic amount of labour, most likely taking years, in order to produce this literary work, which he then sold on for publishing. The amount of work involved is hugely disproportionate to the value created, at least in the short term, for capital. This can be distinguished from the hack journalist who appears to only engage in writing specifically because that writing is useful as a saleable commodity, not for any intrinsic worth found within.

This for Marx is the key distinction. Milton's labour is of value not because it produces value for capital, but in the sense that is a labour of the self, it is a labour that expressed something close to Milton's own nature:
Milton produced Paradise Lost in the way that a silkworm produces silk, as the expression of his own nature... the Leipzig literary proletarian who produces books... at the instructions of his publisher is roughly speaking a productive worker, in so far as his production is subsumed under capital and only takes place for the purpose of the latter's valorization (1976: 1044)

Here is the key difference. Milton's labour in writing is not producing value for capital, but is only value producing when it enters into circuits of commodity production and exchange. Marx extends this analysis following with the image that a singer who sings like a bird is an unproductive worker, but once she sells that capacity to sing as a form of labour power, then she produces directly produces capital. This is a clear statement of the well-known distinction Marx makes that value for capital is only produced by labour enmeshed in circuits of commodity production and exchange, which has been debated and disputed. 
What is more interesting than the productive and unproductive distinction is what Marx attributes to Milton's labour before it becomes enmeshed in circuits of commodity production. For Marx this labour that is unproductive for capital is like the silkworm producing silk, which is to say that it is not motivated by the prospect of external reward, but because it is an intrinsic part of silkworm's nature. The work of the silkworm is an expression of its intrinsic nature rather than something developed or motivated by external reward. If the silkworm were a cultural worker it would probably tell Marx, or us, that it is only concerned about developing its own practice rather than commercial concerns.

In the context of changing psychological contracts around cultural work there is a clear drive to transform increasing parts of work, so that they are experienced by the worker as the expression of the worker's own nature - much like a silkworm producing silk. If work is experienced or perceived as flowing directly from one's own creative nature then it is not, more often than not, even recognized as work. This is the idea that underpins the entire celebrated mantra of 'doing what you love' as a way to escape the drudgery of work and routine into conditions, in which work and play blend into a winning situation of turning one's passion into an activity that one can live off of, at least in theory (Tokumitsu, 2015). Here, psychological contracts operate as a form of normative control, giving workers the impression that there is a reciprocal bargain that the employer or client will live up to (without any necessary guarantee that this will be the case). Or as John Budd frames it, the "true power of psychological contracts... might be in making a hierarchical employment relationship seem balanced to employees and thereby providing legitimacy for the existing social order" (2011: 114).

There seems to be an ideological celebration of work that is part of one's own nature. The problem with this is that such celebration does not mean that such work magically becomes a viable means of actually supporting oneself. Rather there is a value in this idea despite that it is far from a realistic option for many people. Here can be seen an example of what Jason Read, following Foucault, describes as neoliberalism's formatting as subjectivity (2009), its demands that we are to be entrepreneurs of ourselves. Neoliberalism in this view is not just about changing conditions of regulation or governance of social structure, but about producing certain kinds of social relationships, in particular the shaping of subjective experiences of self in relationship with work, encouraging people to view themselves as human capital.

In this way, we can connect Beuys' claim that everyone is an artist with Marx's description of Milton's labour being of his own nature. By developing perceptions of certain forms of work as being of intrinsic value, as producing our own nature, we can draw a connection to understanding work as a form of human capital creation. In this way authentic forms of labour, as expressions of the self, come to function as a form of regulating and intensifying work. This can be seen not just within the importance often held by artists and cultural workers to seek out meaningful work, but also in how notions of authentic expression and meaningful work become adopted as corporate policies. Or as Peter Fleming has put it (2009), the guiding motto for workers becomes to 'just be themselves,' but this is no longer a 
choice but a requirement, and a new form of informal control that operates through the appearance of its informality and desirability.

Who would not want to work in an environment where work is meaningful, where you can be yourself? At face value it is difficult to even argue against such notions that present themselves as inherently positive and unproblematic without a good degree of unpacking their contradictions and hidden forms of discipline. But what does it mean when wanting to engage in forms of authentic and meaningful work have shifted into a form of labour discipline? This is especially the case when the motivating desire to finding authenticity and meaning in work becomes part of leading one into accepting precarious conditions or arrangements. Precarity is thus not just about the formal job status, but also regulating the production of subjectivity in relationship with work itself. It is part of producing what Fleming calls the 'I, job' function, or where our very sociality is now deeply implicated as part of the production process $(2015){ }^{7}$

\section{Social Reproduction \& the Underpinning of Cultural Work}

Reflecting on matters of social reproduction, we see similarities between embodied artistic and creative labour to gendered instances of reproductive labour. If work is seen as part of oneself - in this sense, highly invested, embodied creative work, work that becomes one's life and vice versa - it is similar to various instances of gendered, feminised types of labour that are involved in processes of daily social production and reproduction, carework, and housework. In a similar manner this kind of work, artistic and feminised labour, is dependent on the wider social networks of informal and flexible support and assistance. In the past, the feminised work of social reproduction in the home would have depended on the single wage of a Fordist worker (male) while it simultaneously made his work possible and sustainable in the first place. In the current climate of increasing precarity, artistic and creative work depends increasingly on family money, inherited property, as well as parental, sibling or spousal income and support. This artistic and creative production is also dependent on extrafamilial, less formalized means of support such as mutual childcare provision, vegetable coops, and skills exchanges ${ }^{8}$.

Even highly autonomous and individualized workers who perhaps stay away, consciously, from collaborative ways of working and value production rely on such relationships and collaborations in order to be able to survive and continue with their creative practices. These types of artistic work could be looked at from the perspective of 1970's feminist work, Wages for Housework and Silvia Federici's ideas (2012, 2017). Further, instances of unpaid work, labour of self-investment and nurturing social connections, networking and so on - not necessarily just in the creative sector or in the arts, although here the similarity to feminised work in the home is more obvious - in order to be considered as work, can be thought about in the way Wages for Housework thought of labour of social production and reproduction or housework in the home. In order to discuss such activities in terms of work, a demand for a wage - although Wages for Housework never did demand, in earnest, to be paid for such activities - needed to be made in order to refuse such work. 
Many of the cultural producers who are being pushed out from newly gentrified areas cannot afford a separate studio space or paid access to a co-working space and so they take their work back into the home, or indeed, it has never left the domestic setting in the first place. This is of course, in a sense - ironically - correspondent to the trajectory of types of art and craft work that was initially predominantly feminised work and only left the home and entered the sphere of value production at the time of the industrial revolution (alongside the work of children and women) only to return to the sphere of the domestic yet again. This overlap between domestic work and unpaid work clearly affects both the working and domestic situation - looking after the kids or further relying on family for help with work and or accommodations, the strain this type of work has on relationships, etc. - this being generally the caring and affective labour performed by women, it further affects this category of workers.

\section{Precarity as the Governance of Cultural Labour}

the social precariousness of employment is not just a matter of occupational insecurity and labour market uncertainty, but is shaped by the mismatch between the official imagination of work and significations derived from its ordinary material experiences. - Franco Barchiesi (2011: 24)

Shifts in the psychological and social contract of cultural labour are thus part of this formatting of subjectivity as demanded and required by neoliberalism. This operates most effectively when the deep investment required in the work itself presents itself not as a burden or a risk, but rather as something desirable and enjoyable. Gina Neff, Elizabeth Wissinger, and Sharon Zukin describe how this can be seen in "how entrepreneurial labour becomes intertwined with work identities in cultural industries both on and off the job" (2005: 307) for media and cultural workers. Workers are drawn into and find working in these industries desirable because of the cool factor associated with them, as well as the allure of work that is thought to have a high degree of autonomy, creativity, and excitement, and thus came to accept the risks that are also associated with such forms of work, to know no weekends. Going to a party after work is no longer just going to a party, but also an occasion for compulsory networking, for meeting the requirements of being seen at the right place at the right time to maintain a certain image required for work.

A great amount of time and work, or rather, entrepreneurial labour is spent on networking, maintaining both closer and more distant contacts and relationships with people in the industry in order to provide the next job, the next gig, or even just to remain visible in the field. This is of course all unpaid labour, but labour that can be seen as part of being an entrepreneur of the self, a work or investing, or perhaps speculating on one's human capital. This kind of entrepreneurship, or 'social self-investment' can be seen in unpaid internships in the creative and cultural sector (Hope and Figiel, 2015). Just as there are now many similarities between the artistic and cultural mode of production and other spheres of the post-Fordist and now highly precarious economy, there are similarities between the kinds of unpaid labour required on the part of recent graduates and interns, and the unpaid, invisible 
labour of artistic and cultural workers struggling to stay afloat in the weekend-less, precarious economy.

Neff has explored further how this dynamic of psychological and social self-investment does not confine itself to occupations more obviously thought of as artistic and cultural, but is embraced more widely across tech and media sectors. She describes this phenomenon as venture labour, or the "investment of time, energy, human capital, and other personal resources that ordinary employees make in the companies they work. Venture labour is the explicit expression of entrepreneurial values by non-entrepreneurs" (2012: 17). What Neff calls venture labour is a space where the expanded and transformed psychological contract of work that was seen in the arts is expanded into other areas. Venture labour for Neff describes how workers are convinced to take on risks and apply themselves harder to their work because they perceive these actions as having the character of future investment in better outcomes which may not be monetary at all, but are rather more related to the success of the firm or the project. In other words, even if they do not explicitly think about it in such terms, the venture labourer has become willing to apply themselves to their work much like Milton as silkworm, as engaging in a labour of their own nature, which they are committed, more for the intrinsic reward of it than economic benefit. But the key difference here is that this does not mean that the tech workers Neff describes actually have ownership or investment in the company in a formal way where they will benefit from it. Venture labour describes their willingness to work as if they did, out of their psychological and social investment in the work, despite that not being the case. Through this intensified psychological investment in work the imagination of the future becomes financialized. It is subject to the continued demands of capital's continued valorization, its expected return on investments. Except these workers are not even themselves directly as financialized as much as this relationship, governing the imagination of the future, is culturally mediated through their relationship with work.

It could be argued that these kinds of venture labour appropriate and reproduce the mechanisms of gendered unpaid reproductive and domestic labour, specifically, the invisible care and maintenance that workers perform both on themselves and for the organizations they work for. Rather than acknowledge these activities as exploitative forms of unpaid labour however, they are often presented as necessary (even desirable) investments, both for the artistic and cultural worker - and beyond, as well as more generally for a functioning, productive, profitable society. ${ }^{9}$

Venture labour operates as an effective form of governing forms of labour that are less amenable to more traditional workplace discipline precisely for how it encourages workers to embrace economic risk, but without any guarantee of reward or security. Neff argues that embrace of risk, in individualized form, "does not bode well for organizing collective, social responses to support work in innovative industries" (2012: 36). This echoes arguments previously made by Angela McRobbie about how cultural and media workers are expected to operate as 'microstructures,' taking on all the tasks associated within managerial labour, but to absorb them into their own work (McRobbie, 2002). In both cases, it is suggested that this 
embrace of risk, the shift of the psychological and social contract of work, operate to effectively block off what previously had the possibility of acting as a starting point for collective organizing around a form of work. Both of these dynamics function as part of what Franco 'Bifo' Berardi describes as the slow cancellation of the future which began during the 1970s and 1980s, emerging with the rise of neoliberalism (2011). Likewise, Mark Fisher describes how this erosion of the future, and of the imagination of possible futures, has served to deflate expectations of what can be accomplished through collective organizing (2014).

It is in this sense of blocking off or pre-empting labour organizing, which is to say functioning as a form of governing labour, that the transformed psychological and social contract of work connects with the question of precarious labour and conditions. This can be clearly seen in Guy Standing's work on the emergence of the precariat as a distinctive class, in which he argues that the precariat has distinct class characteristics based on having minimal trust relationships with capital or the state, which is to say with the organizational forms that have previously governed the employment relationship (2018). Standing argues that precarious workers today no longer have or can fall back on the social contract relied upon by the proletariat during Fordism, namely where "labour securities were provided in exchange for subordination and contingent loyalty, the unwritten deal underpinning welfare states" (2011: 8). Standing argues that the class position of precarious workers is unique precisely because of this shift in expectations, the lack of a bargain of security for subordination, which previously existed. Instead workers are faced with, as argued by Melissa Gregg, with an expectation of high investment and commitment in their work, but with no guarantee of any security. Standing suggests that precarious workers have a truncated status, one that does not map easily onto high status professional or middle class occupations, even if it is held together by the psychological and social celebration of these forms of work as meaningful and rewarding.

This truncated status easily becomes a continual source of uncertainty due to the mismatch between expectations and realities. Work is supposed to be highly rewarding and fulfilling, characterized by creativity and self-organization, yet that is more often than not coupled with uncertainty about whether contracts will be continued, whether new projects will pan out, what conditions can be expected tomorrow. For these reasons, it perhaps no surprise at all that it would be claimed, as it has been by the Institute for Precarious Consciousness, that the dominant affective structure is precisely one of anxiety (2014). The Fordist production line and the welfare state might have brought about conditions of a more secure survival, though often argued by dissidents from the Situationists to the Sex Pistols, to be paired with misery and boredom. Today we no longer struggle to escape from the boredom of predictability and security, but rather worry and are anxious about loss of status, subsistence, or other conditions. Precarious cultural and artistic workers discover that their freedom and autonomy is purchased at the price of buying into what Franco 'Bifo' Berardi describes as the psychopathologies of immaterial and informational work, the way that it overloads abilities to process and communicate (2009). 
In this way, the conditions of precarious work fundamentally alter the relationship between wage and income, as payments received for temporary work (particularly within the arts and cultural sector) are often not enough to support one's existence. If temporary work cannot be relied upon for supporting material sustenance, even while it is being relied upon as a form of psychological wage or sustenance of sense of identity and meaning, then it becomes necessary to find all kinds of means and strategies to make ends meet. Monthly budgets are precariously balanced on managing credit debts, leading to what Randy Martin described to aptly as the financialization of daily life, as well as conceptions of the future that emerge from these everydays (2002). This may take the form of taking up additional work unrelated to one's practice in order to support working in the arts and culture sector, or finding other means of support, or constantly developing other skills and capacities that may become useful in obtaining future work and/or support for one's artistic-cultural practice. And it is by this acting as entrepreneurs of self-demanded by the neoliberal formatting of subjectivity where workers develop

across their lifetime, in the workplace and at home, behavioural, communicative, and cognitive skills needed to face employment risks, compete in uncertain labour markets, and cope with frequent jobs changes. To the extent that workers acquire such capacities outside the conventionally defined working hours, employers can appropriate them at no cost (Barchiesi, 2011: 124)

But why would workers be willing to acquire new skills and capacities outside of working hours if such are going to be freely appropriated at no cost? Again, here can be seen how the expanded psychological and social contract of work operates, as such can be justified it can be seen to part of supporting and making possible one's form of artistic or cultural practice. Or beyond the relatively narrow area of artistic and cultural work it is the upskilling demanded that today's venture labourers must continually participate in, in order to demonstrate their continued investment in working conditions that continue not guarantee them any security but rather continue to demand ongoing displays of this deep-seated investment in work without any guarantees.

This is what Isabell Lorey described as when precarity becomes a form of governmentalization (2015). That is, when precarious conditions are not just about changing the conditions of work, or the withdrawal of regulations or protections that once existed, but seek to actively change the ways in which subjectivity is formed. For Lorey this governmental precarization is not only about changing the conditions of employment, but also the "destabilization of the conduct of life and thus of bodies and modes of subjectivation" (2015: 13). And most importantly this transformation in subjectiviation through becoming precarious for Lorey is no longer a marginal phenomenon, but indeed have arrived at what she describes as the 'social middle' where "[p]recarious living and working conditions are increasingly normalized at a structural level... the society we currently live in is by no means an insecurity society, it is indeed still a security society, but it is one that can be controlled through social insecurity" (2011). Here Beuys embrace of knowing no weekend 
shifts from enabling a new possibility for his work, to functioning as a kind of model of governing labour.

\section{Conclusion: Ambivalence \& Passion}

We have to face up to the fact that there is no automatically available road to resistance and organization for artistic labour. That opportunism and competition are not a deviation of this form of labour but its inherent structure. That this workforce is not ever going to march in unison, except perhaps while dancing to a viral Lady Gaga imitation video. The international is over. Now let's get on with the global. - Hito Steyerl (2009: 35)

After reading thus far, where does this leave questions about the nature of cultural and artistic labour if indeed our relationship to it has changed through an expansion of the psychological and social contract of work? If we are, or were, attracted to working in the words of artistic and cultural production because of their formation around what Angela McRobbie (2016) calls "passionate work," what can be done when it is precisely that passionate attachment to work that serves to facilitate and make possible conditions of even more intense exploitation, that makes bearable forms of precarity that would otherwise be rejected? What are you willing to accept in order to sustain the burden of your passion? Is it necessary to jettison the entire idea of meaningful and fulfilling work because of this, and if so, in favour of what?

We would suggest that is not the case. As gestured to in the quote from Hito Steyerl above, there is no automatically available approach for the organizing of artistic and cultural labour, including a wholesale rejection of passionate motivation and attachment to the work itself. Rather it is a question of working through ambivalent genealogies of precarious work, creativity, and motivation that have led us to the present. And working through them not to discard them, but rather to reclaim the utopian potentials that can still be found within the condition of the realization of Beuys' claim that everyone is an artist. How can we become creators not just of exploitable forms of creativity, but of other ways of producing and live together? How is it possible to refuse work from a position of a precarious worker, who only ever had an intermittent, unfulfilling, temporary and/or underpaid relationship to the very work that also defines her subjectivity and psychologically? As Kathi Weeks suggests, many of the numerous problems with work today are tied to the hegemony of the work ethic, which today "is even more central because in forms of post-Fordist production there is an enormous need for workers willing to invest their subjectivity and to identify with their work" (Curcio and Weeks, 2015).

In Italy during the rise of autonomist movement in the late 1970s it was proclaimed that precarity was a beautiful thing. This beauty was celebrated because it was an escape from the controls of boredom of the Fordist factory line into something new and unexpected, attempts to find new ways to live through self-organized forms of work, living, and cultural activity (Berardi, 2009). Of course, this embrace of precarity and uncertainty would no longer have the same appeal, present itself with the same beauty, once the rollback of the welfare state 
and the undermining of other forms of material and psychological security meant that precarity was no longer a choice to be embraced by those who desired it but a condition to be endured by all. And it is in this sense that precarious labour and our investments in it, whether in cultural and artistic work, is ambivalent. Gigi Roggero argues that it is ambivalent in a strong sense, as space of conflict that is not dialectical in the more traditional Marxist sense, but rather "a field of antagonistic forces, focusing on the new terrain of conflict and its possibilities outside of every deterministic premise, therefore illustrating its elements of historicity and contingency" (2011:21).

Such is the ambivalence of passionate work: not wanting to let go of it, not wanting to be done with forms of work that drive us so that not knowing the weekend might indeed be fully justified. Ambivalence, not as a mere discomfort, but meaning, in a deeper sense, that transformations in labour contain a possibility to go in two very different directions: towards a financialized future desire to capital accumulation, or a struggle towards a future where creativity forms the basis of new horizons for cooperation and solidarity. The problem lies in finding ways to channel this desire into forms of work that are not premised on accepting precarity as its precondition. In other words, it would make no sense to dismiss the desires of cultural workers to find meaning and fulfilment in their work, to tell them that these desires allow them to be exploited and should be done away with. The question what becomes possible, in terms of reclaiming of a utopian imagination, starting from how these desires are cramped within the spaces afforded within these precarious times. We still want to know weekends, even if they do not fall on Saturdays and Sundays. We must reclaim the utopian dream of a self-organized future rather than succumb to its slow cancellation brought on by neoliberalism and its financialized governance of culture, labour, and life in general. There may indeed be no readymade road to resistance for artistic and cultural labour, but that does not mean that there is no use in constantly re-inventing new forms of labour solidarity and organizing. To know the weekend again means not falling back into a Faustian bargain that understands creative work as meaningful only when it is all encompassing, and thus becomes a pretence for destroying the very conditions that make such work and creativity possible to begin with. 


\section{References}

Abbing, H., 2004. Why Are Artists Poor? The Exceptional Economy of the Arts. Amsterdam: Amsterdam University Press.

Adorno, T. ,1997. Aesthetic Theory. London: Continuum.

Alberro, A. and Stimson, B. Eds., 2009. Institutional Critique: An Anthology of Artists' Writings. Cambridge: MIT Press.

Aranda, J. B.K. Wood, and Vidokle, A., 2011. Are You Working Too Much? Post-Fordism, Precarity, and the Labor of Art. Berlin: Sternberg Press.

Barchiesi, F., 2011. Precarious Liberation: Workers, the State, and Contested Social Citizenship in Postapartheid South Africa. Albany: SUNY Press.

Berardi, F., 2009. Precarious rhapsody: Semiocapitalism and the pathologies of the postalpha generation. London: Minor Compositions.

Berardi, F., 2011. After the Future. Oakland: AK Press.

Bryan-Wilson, J. 2009. Art Workers: Radical Practice in the Vietnam War Era. Berkeley: University of California Press.

Budd, J., 2011. The Thought of Work. Ithaca: Cornell University Press.

Clammer, J., 2014. Vision and Society: Towards a Sociology and Anthropology from Art. London: Routledge.

Curcio, A. and Weeks, K., 2015. "Social Reproduction, Neoliberal Crisis, and the Problem with Work: A Conversation with Kathi Weeks," Viewpoint Issue 5. Available at https://viewpointmag.com/2015/10/31/social-reproduction-neoliberal-crisis-and-theproblem-with-work-a-conversation-with-kathi-weeks/

Diederichsen, D., 2008. On (Surplus) Value in Art. Berlin: Sternberg.

Federici, S., 2012., Revolution at Point Zero: Housework, Reproduction, and Feminist Struggle. Oakland: PM Press.

Federici, S. and Austin, A., 2017. The New York Wages for Housework Committee 19721977. History, Theory and Documents. New York: Autonomedia.

Fisher, M., 2014. Ghosts of My Life. Winchester: Zero Books.

Fleming, P., 2009. Authenticity and the Cultural Politics of Work: New Forms of Informal Control. Oxford: Oxford University Press.

Fleming, P., 2015. The Mythology of Work: How Capitalism Persists Despite Itself. London: Pluto Books.

Fraser, A., 2005. From the Critique of Institutions to an Institution of Critique. Artforum Vol. 44 Issue 1: 278-285.

Gielen, P., 2009. The Murmuring of the Artistic Multitude: Global Art, Memory and PostFordism. Amsterdam: Valiz.

Gill, R. and Pratt, A., 2008. Precarity and Cultural Work: In the Social Factory? Immaterial Labour, Precariousness and Cultural Work. Theory, Culture \& Society Vol. 25 (7-8): 1-30.

Gregg, M., 2011. Work's Intimacy. London: Polity.

Hanlon, G., 2015. The Dark Side of Management: A Secret History of Management Theory. London: Routledge.

Hope, S. and Figiel, J., 2015. "Interning and Investing: Rethinking Unpaid Work, Social Capital, and the "Human Capital Regime," tripleC 13(2): 361-374. Available at http://www.triple-c.at 
Kálmán, R. and Šević, K., 2010. We Are Not Ducks on a Pond But Ships at Sea: Independent Art Initiatives in Budapest 1989-2009. Budapest: Impex.

Klamer, A., 1996. The Value of Culture: On the Relationship between Economics and Arts. Amsterdam: Amsterdam University Press.

Konings, M., 2015. The Emotional Logic of Capitalism. Stanford: Stanford University Press.

Lorey, I., 2011. “Governmental Precarization,” Transversal Number 8. Available at http://eipcp.net/transversal/0811/lorey/en

Lorey, I., 2015. State of Insecurity: Government of the Precarious. London: Verso.

Martin, R., 2002. Financialization of Daily Life. Philadelphia: Temple University Press.

Marx, K., 1976. Capital: Volume 1. London: Penguin Books.

McRobbie, A., 2002. "Clubs to Companies: Notes on the Decline of Political Culture in Speeded Up Creative Worlds," Cultural Studies 16, no. 4: 516-31.

McRobbie, A., 2016. Be Creative: Making a Living in the New Culture Industries. Cambridge: Polity.

Mitropoulos, A., 2012. Contract and Contagion: From Biopolitics to Oikonomia. New York: Autonomedia.

Neff, G, E Wissinger \& S Zukin (2005) Entrepreneurial Labor among Cultural Producers: “Cool” Jobs in "Hot” Industries. Social Semiotics Volume 15 Number 3: 308-333.

Neff, G., 2012. Venture Labor. Cambridge: MIT Press.

Pink, D., 2010. Drive: The Surprising Truth About What Motivates Us. Edinburgh: Canongate.

Raunig, G. and Ray, G., Eds., 2009. Art and Contemporary Critical Practice: Reinventing Institutional Critique. London: MayFly Books.

Read, J., 2009. "A Genealogy of Homo-Economicus: Neoliberalism and the Production of Subjectivity" Foucault Studies Number 6: 25-36.

Ross, A., 2009. Nice Work If You Can Get It: Life and Labor in Precarious Times. New York: New York University Press.

Rossiter, N. and Lovink, G. Eds., 2007. MyCreativity Reader: A Critique of Creative Industries. Amsterdam: Institute of Network Cultures.

Rousseau, D., 1995. Psychological Contracts in Organizations: Understanding Written and Unwritten Agreements. London: Sage.

Sholette, G. and Ressler, O., 2013. It's the Political Economy, Stupid: The Global Financial Crisis in Art and Theory. London: Pluto.

Shukaitis, S. and J. Figiel. 2013. "Metropolitan Strategies, Psychogeographic Investigations," Cultural Studies $<=>$ Critical Methodologies Volume: 13 issue: 6: 536-543.

Shukaitis, S., Figiel, J. and Walker, A., Eds. 2014. ephemera: theory \& politics in organization Volume 14 Number 3, issue on "The Politics of Workers' Inquiry."

Shukaitis, S. and Figiel, J., 2015. "The Factory of Individuation: Cultural Labor \& Class Composition in the Metropolis," South Atlantic Quarterly Volume 114 Number 3: 535552.

Siebert, S. and Wilson, F., 2013. "All Work and No Pay: Consequences of Unpaid Work in the Creative Industries." Work, Employment and Society 27, no. 4: 711-21.

Siegelbaum, S., 2013. Business Casual: Flexibility in Contemporary Performance Art. Art Journal 72, no. 3: 48-63. 
Standing, G., 2011. The Precariat: The New Dangerous Class. London: Bloomsbury Academic.

Steyerl, H., 2009. "The Institution of Critique," Art and Contemporary Critical Practice: Reinventing Institutional Critique. Gerald Raunig and Gene Ray, Eds. London: MayFly Books: 13-29.

Steyerl, H., 2010. "Politics of Art: Contemporary Art and the Transition to Post-Democracy," e-flux \# 21, December 2010. Available at http://www.e-flux.com/journal/21/67696/politicsof-art-contemporary-art-and-the-transition-to-post-democracy/

Terranova, T., 2004. Network Culture: Politics for the Information Age. London: Pluto. Tokumitsu, M., 2015. Do What You Love: And Other Lies About Success and Happiness.

New York: Regan Arts.

Wherry, F., 2012. The Culture of Markets. Cambridge: Polity.

Zukin, S., 1989. Loft Living: Culture and Capital in Urban Change. New Brunswick: Rutgers University Press.

\begin{abstract}
${ }^{1}$ Denise Rousseau (1995) defines the psychological contract as the nature of expected duties and obligations around work, which are not just formally specified within contracts but embedded whole range of cultural norms and understanding about work. Rousseau differentiates the psychological contract as the relationship between an individual and a particular organization, and the expectations and norms involved in that employment relationship, from the social contract of work, which she describes as being "cultural, based on shared collective beliefs regarding appropriate behaviour in a society" (1995: 13). While there is some methodological sense in this distinction when looking at the 'traditional' and relatively stable employment relationship between an individual and a formal and generally stable organization, this becomes blurrier in the workings of dispersed networks of collaboration that characterize freelance cultural workers. In this sense, the psychological contract of work always connects to the social contract of work, and thus for this essay we tend to
\end{abstract} blur the distinctions between them.

2 The materials for this essay were generated in the Metropolitan Factory research project organized by Stevphen Shukaitis and Joanna Figiel. For more on this project and initial writing coming out of it see Shukaitis and Figiel (2015), as well as the ephemera special issue on workers' inquiry (2014). The first essay focused mainly on issues specifically concerned with cultural workers around Brick Lane in London. This essay explores concerns coming from the research more generally.

${ }^{3}$ For more on this see Bryan-Wilson.

${ }^{4}$ One of the main source for rethinking the role of labour and politics in participatory media that draws heavily on the work of Hardt and Negri as well the traditions of thought that draw from is Tiziana Terranova's writing on the function of "free labour" within network cultures (2004). Terranova's analysis of free labour as both exploited and enjoyable, and as functioning as a necessary feature of networked forms of immaterial labour, has functioned as a key nodal for in the development of research using autonomist concepts. This connects back to a larger project of class composition analysis, and in particular as a form of worker's inquiry. The notion of worker's inquiry, developed within autonomist movements, was not meant as a way to develop new sociological categories, bur rather to understand the transformations of forms of labour that were occurring from within them, and from that the political possibilities that they contain. In terms of the potential they keep open for antagonistic social analysis, we would locate their usefulness in terms of bringing back to serious consideration a notion of class for conceptualizing media practices, cultural labour, and related dynamics, but a notion of class that is nowhere near as reductive as the more economistic analysis with which Marxism is often associated. Furthermore, an autonomist approach to understanding changes in media and cultural labour emphasizes that forms engagement currently employed by capital to eek out more and more surplus value (e.g. unpaid cultural labour, free labour) are precisely the potential of previous practices that have been rendered into new modes of accumulation (Gielen, 2009; Ross, 2009; Gill and Pratt, 2008; Rossiter and Lovink, 2007). The key point is to understand the ways that a process of class decomposition, turning resistance into new forms of capitalist valorization, occurs such that it can be worked through, around, and against.

${ }^{5}$ For some recent writing and analysis of the shifting relations between art and labour see Aranda, Wood, and Vidokle, 2011; Banks, 2007; Diederichsen, 2008; Klamer, 1996; Abbing, 2004; Sholette and Ressler, 2013; Siebert and Wilson, 2013; Siegelbaum, 2013; Kálmán and Šević, 2010; and Wherry, 2012.

${ }^{6}$ See for example: http://www.bbc.com/culture/story/20170419-why-paradise-lost-is-one-of-the-worlds-mostimportant-poems 
${ }^{7}$ But as Gerald Hanlon argues (2015), the involvement of subjective, personal traits, in the work process, could also be argued not to be new, but rather extending dynamics already found within capitalism. A longer term and larger scope analysis of this issue would look not just at it within the working of the cultural economy, but rather as a more fundamental aspect of capitalism itself which if anything has become more pronounced rather than being a new development.

${ }^{8}$ As evidenced in the interviews conducted for the Metropolitan Factory research project, see endnote above. ${ }^{9}$ Angela Mitropoulos (2012) argues the neoliberalism and post-Fordism represent a complex rewriting and transformation of the social contracts underlying conceptions of the family, sexuality and social reproduction, which is co-articulated through overlapping dynamics of gender, race, citizenship and borders. It is not surprising that this affects the workings of cultural production as well. 